\title{
IMPLEMENTASI KETENTUAN RESTRUKTURISASI KREDIT TERHADAP DEBITUR WANPRESTASI PADA KREDIT PERBANKAN
}

\author{
Oleh: \\ Putu Eka Trisna Dewi ${ }^{1}$
}

\begin{abstract}
The high percentage of non-performance loan (NPL) may bring adverse impact to creditor (banks), the banking sector in general, and also to the economic and financial of the country. To overcome these conditions, Bank of Indonesia issued a policy regarding restructuring. Restructuring is an effort undertaken in the activities of credit to borrowers who have difficulty to meet its obligations. Banks engaged in lending has a restructuring program has been set on the credit policy of each bank, but still there are banks that ignore and do not do this loan restructuring seek in accordance with the procedure.

This study is an empirical study that examines the juridical on the implementation of the rules concerning the restructuring of the debtor defaults on bank loans as well as obstacles in implementing the debt restructuring. This research is a descriptive research. Data sourced from primary data and secondary data. Data collection techniques used is literature study and interview techniques. Analysis conducted qualitative and descriptive analysis presented.

Implementation of the provisions of the rescue loan restructuring and settlement of nonperforming loans on bank credit has not been optimally applied to all borrowers who are having trouble paying even though they have the opportunity to carry out the payment. Inhibiting factors, among others, the rules concerning debt restructuring are scattered in various policy rules, regulations often change with a relatively large number of rules, the lack of a comprehensive understanding of this policy, an independent financial consultant is often overlooked involvement in debt restructuring, which is not good faith to implement agreement, the lack of information and initiatives in the debtor filed debt restructuring, customers who do not cooperative and giving false information about the source of income.
\end{abstract}

Keywords: non-performance loan, bank, restructuring and credit.

\section{PENDAHULUAN}

\section{Latar Belakang}

Keberadaan bank dalam kehidupan masyarakat dewasa ini mempunyai peranan yang sangat penting karena lembaga perbankan merupakan inti sari dari sistem keuangan setiapnegara. Perkembangan dunia perbankan di Indonesia kini sudah semakin

Mahasiswa Magister Ilmu Hukum Universitas Udayana, Denpasar, Bali. Alamat Jalan Subak Dalem Perum Griya Loka Kav. Satu Lantai No. 2 Gatot Subroto Tengah, Denpasar Utara, Bali.e-mail: escampur.melon@gmail.com membaik, berbagai pelayanan jasa keuangan telah dikembangkan untuk memberikan kenyamanan bagi para nasabah. Berbagai program perluasan usaha telah dilakukan dalam industri perbankan seperti pemberian kredit perumahan, penyediaan jasa asuransi, penawaran jasa kartu kredit hingga program pensiun. Secara lebih spesifik bank dapat berfungsi sebagai agent of trust (lembaga yang landasannya adalah kepercayaan), agent of development (lembaga yang memobilisasi dana untuk pembangunan ekonomi) dan 
agent of services (lembaga yang memberikan penawaran jasa perbankan). ${ }^{2}$

Penyaluran dana kepada masyarakat yang dilakukan oleh bank pada umumnya dalam bentuk pemberian kredit, baik itu berupa kredit modal kerja maupun kredit investasi. Di samping kegiatan pengerahan dana kepada masyarakat, kredit juga merupakan kegiatan utama dari bank-bank umum di Indonesia. Walaupun kegiatan penyaluran kredit merupakan kegiatan perbankan yang sangat mendasar dan bunga kredit merupakan sumber pendapatan bank yang utama tetapi pada dasarnya kegiatan penyaluran kredit ini memiliki risiko yang sangat besar dan dampak yang signifikan bagi kelangsungan usaha bank tersebut apabila kredit yang disalurkan tersebut tidak tepat.

Apabila debitur banyak yang tidak melakukan kewajibannya dalam hal ini melakukan wanprestasi tentu saja akan berdampak serius yaitu krisis terhadap sektor perkreditan yang ditunjukan dengan besarnya rasio non-performance loan (NPL) pada bank tersebut. Tingginya rasio nonperformance loan (NPL) tentunya akan sangat membahayakan kesehatan dari bank tersebut. Sebagai upaya mengatasinya Bank Indonesia (BI) menetapkan kebijakan restrukturisasi kredit. Restrukturisasi kredit merupakan suatu terminologi keuangan yang banyak digunakan dalam bidang perbankan untuk menyelamatkan kredit bermasalah. Restrukturisasi adalah program bank sebagai

Sigit Traindaru dan Totok Budisantoso, 2007, Bank dan Lembaga Keuangan Lain, Salemba Empat, Jakarta, hlm.8. suatu upaya perbaikan yang dilakukan dalam kegiatan perkreditan terhadap debitur yang mengalami kesulitan untuk memenuhi kewajibanya.

Program restrukturisasi kredit umumnya telah lazim dilakukan di dunia perbankan. Bank yang bergerak pada penyaluran kredit memiliki program restrukturisasi telah diatur pada kebijakan perkreditan masing-masing bank, namun masih ada bank yang mengabaikan dan tidak melakukan restruturisasi kredit ini sesuai dengan prosedur, misalnya melakukan write-off bersamaan dengan restrukturisasi kredit dimana restrukturisasi kredit ini hanya merupakan formalitas agar write-off bisa dilakukan dan bank bisa mendapatkan bunga tunggakan yang besar dari debitur dengan kategori kredit bermasalah.

Selain hal di atas, kecenderungan kreditur dalam hal ini bank tidak melakukan restrukturisasi kredit pada debitur yang tergolong kredit bermasalah karena tergiur akan keuntungan dari penjualan agunan kredit di bawah tangan. Dengan penjualan agunan kredit di bawah tangan tentunya akan menghemat waktu dan kreditur tidak kehilangan keuntungan dari bunga kredit debitur yang semakin besar selama debitur tidak mampu membayar. Permainan harga pun dapat diatur sedemikian rupa.

Berdasarkan latar belakang masalah tersebut di atas, kiranya cukup alasan untuk diadakan suatu penelitian dan pembahasan mengenai hal-hal yang berhubungan dengan masalah "Implementasi Ketentuan Restrukturisasi Kredit Terhadap Debitur Wanprestasi Pada Kredit Perbankan" 


\section{Rumusan Masalah}

Permasalahan dalam penelitian ini adalah sebagai berikut:

1) Bagaimanakah implementasi ketentuan restrukturisasi kredit dalam penyelamatan dan penyelesaian kredit bermasalah pada kredit perbankan?

2) Apa hambatan yang dihadapi dalam implementasi ketentuan restrukturisasi kredit dalam penyelamatan dan penyelesaian kredit bermasalah pada kredit perbankan?

3. Tujuan Penulisan

a. Tujuan umum (het doel van het onderzoek).

Tujuan umum dalam penelitian ini adalah untuk mengetahui permasalahan hukum dan isu-isu aktual mengenai perbankan, yakni mengenai implementasi ketentuan restrukturisasi kredit terhadap debitur wanprestasi pada kredit perbankan.

b. Tujuan khusus (het doel in het onderzoek).

Tujuan khusus dari penelitian ini adalah:

Untuk menganalisis implementasi ketentuan restrukturisasi kredit dalam penyelamatan dan penyelesaian kredit bermasalah pada kredit perbankan.

1) Untuk menganalisis hambatan yang dihadapi dalam implementasi ketentuan restrukturisasi kredit dalam penyelamatan dan penyelesaian kredit bermasalah pada kredit perbankan.

\section{METODE PENELITIAN}

a. Jenis penelitian.

Jenis penelitian ini adalah penelitian hukum empiris yang mengkaji mengenai implementasi mengenai ketentuan restrukturisasi terhadap debitur wanprestasi pada kredit perbankan serta hambatanhambatandalammelaksanakanrestrukturisasi kredit tersebut.

b. Sifat penelitian.

Penelitian ini adalah penelitian yang bersifat deskriptif, dimana akan dideskripsikan secara sistematis, faktual, dan akurat mengenai pelaksanaan ketentuan restrukturisasi dalam penyelamatan kredit bermasalah dan perlindungan hukum terhadap nasabah yang tergolong dalam kredit bermasalah dalam restrukturisasi perbankan.

c. Data dan sumber data.

1) Data primer.

Data primer adalah data yang diperoleh dan bersumber dari penelitian lapangan. Jadi terkait dengan penulisan ini, data primer bersumber dari hasil penelitian di Bank Tabungan Pensiunan Nasional (BTPN) dan Bank Perkreditan Rakyat Aruna Nirmaladuta. Wawancara dilakukan kepada komisaris utama dan bagian kredit yang memiliki deskripsi kerja dalam menangani restrukturisasi kredit bermasalah.

2) Data sekunder.

Data sekunder adalah data yang diperoleh dan bersumber dari penelitian kepustakaan. Data sekunder terdiri dari:

a) Bahan hukum primer. Bahan hukum primer yang digunakan sebagai berikut: 
1) Kitab Undang-Undang Hukum Perdata (KUHPerdata)

2) Undang-Undang Nomor tahun 1992 tentang Perbankan sebagaimana diubah menjadi Undang-Undang Nomor 10 tahun 1998 tentang Perbankan.

3) Undang-Undang Nomor 23 tahun 1999 tentang Bank Indonesia.

4) Peraturan Bank Indonesia Nomor: 13/9/PBI/2011 Tentang Perubahan Atas Peraturan Bank Indonesia Nomor 10/18/PBI/2008 tentang Restrukturisasi Pembiayaan Bagi Bank Syariah dan Unit Usaha Syariah.

5) Peraturan Bank Indonesia Nomor 14/15/PBI/2012 Tentang Penilaian Kualitas Aset Bank Umum.

6) Peraturan Bank Indonesia Nomor 15/2/PBI/2013 tentang Penetapan Status dan Tindak Lanjut Pengawasan Bank Umum Konvensional.

7) Surat Edaran No. 15/28/DPNP kepada Semua Bank Umum yang Melaksanakan Kegiatan Usaha Secara Konvensional di Indonesia.

\section{b) Bahan hukum sekunder}

Bahanhukumsekunderyang digunakan adalah literatur-literatur yang membahas mengenai perbankan, aspek hukum perbankan, kredit macet dan restrukturisasi kredit.

d. Teknik pengumpulan data.

Dalam penelitian hukum empiris ini digunakan 3 (tiga) teknik untuk mengumpulkan data yaitu studi dokumen untuk pengumpulan data skunder dan wawancara untuk pengumpulan data primer. Studi dokumen ini dilakukan dalam mengumpulkan data sekunder yang terdiri dari bahan hukum primer, bahan hukum sekunder dan bahan hukum tersier. Wawancara dilakukan di Bank Tabungan Pensiunan Nasional (BTPN) dan Bank Perkreditan Rakyat Aruna Nirmaladuta.

e. Teknik penentuan sampel penelitian.

Sampel adalah himpunan bagian atau sebagian dari populasi³ ${ }^{3}$. Adapun teknik penentuan sampel yang dipergunakan dalam penelitian ini adalah purposive sampling yang digunakan untuk memilih Bank Tabungan Pensiunan Nasional (BTPN) dan Bank Perkreditan Rakyat Aruna Nirmaladuta sebagai lokasi penelitian. Adapun penentuan lokasi penelitian ini didasarkan pada kriteria bahwa di bank-bank tersebut terdapat kredit macet dan restrukturisasi terhadap kredit macet. Snowball Sampling digunakan untuk mencari keberadaan kebijakan restrukturisasi kredit perbankan.

f. Teknik pengolahan dan analisis data.

Teknik pengolahan data menggunakanmetode kualitatif, dengan tujuan agar seorang peneliti dapat mengerti atau memahami gejala yang diteliti. ${ }^{4}$ Kasuskasus yang ditelaah meliputi penentuan kredit bermasalah oleh bank akibat adanya debitur wanprestasi dan kebijakan restrukturisasi di masing-masing bank. Setelah melalui proses

Bambang Sunggono, 2010, Metode Penelitian Hukum, Rajawali Pers PT. Raja Grafindo Persada, Jakarta, hlm.119.

4 Soerjono Soekanto, 2007, Pengantar Penelitian Hukum, Penerbit Universitas Indonesia (UI-Press), Jakarta, hlm.32. 
pengolahan yang selektif, kemudian data tersebut disajikan secara deskriptif analisis, yaitu dijabarkan dalam bentuk uraianuraian yang nantinya dapat menjawab permasalahan mengenai implementasi ketentuan restrukturisasi kredit terhadap debitur wanprestasi pada kredit perbankan.

\section{PEMBAHASAN}

\section{Implementasi \\ Restrukturisasi Kredit}

Ketentuan

Seorang nasabah yang mengajukan kredit wajib memenuhi prestasinya. Prestasi debitur kepada kreditur berupa pembayaran angsuran dengan besar pembayaran, waktu pembayaran dan jangka waktu pelunasan kredit sebagaimana yang tertuang dalam perjanjian kredit yang telah dibuat sebelumnya oleh para pihak.

Berbicara mengenai prestasi maka perlu diketahui hak dan kewajiban bagi para pihak sebagaimana yang tertuang dalam perjanjian kredit. Kreditur pada umumnya memiliki kewajiban untuk memberikan fasilitas kredit dan informasi yang sesuai kepada nasabah debitur serta memiliki hak untuk menerima pembayaran yang terdiri dari akumulasi angsuran pokok, bunga atau denda jika lewat waktu jatuh tempo. Nasabah selaku debitur wajib melakukan pembayaran minimal (tergantung jenis yang dipilih) dan menyerahkan jaminan kepada kreditur. Nasabah memiliki hak untuk mendapatkan fasilitas kredit yang sesuai dan informasi-informasi tentang fasilitas kredit yang diterimanya, misalnya metode pembayaran, lembar penagihan dan lainlain.
Pelaksanaan prestasi oleh debitur kepada kreditur dalam bentuk pembayaran kewajiban atas kredit yang diberikan kreditur (bank) akan menyebabkan kredit lancar dan dalam perhatian khusus, sedangkan apabila terjadi waprestasi maka hal inilah yang menyebabkan terjadinya kredit bermasalah.

Salah satu risiko utama perbankan adalah kredit bermasalah. Apabila jumlah kredit bermasalah sudah melampaui batas kemampuan bank, ia dapat berubah menjadi bencana, sebab tidak saja profitabilitas bank yang akan terkena, likuiditasnya pun terancam. ${ }^{5}$ Dalam menangani kredit bermasalah tersebut, maka salah satu upaya yang dapat dilakukan adalah melakukan restrukturisasi kredit. Restrukturisasi kredit hanya dapat dilakukan atas dasarpermohonan secara tertulis dari nasabah dengan kategori kualitas kredit kurang lancar, diragukan dan macet.

Kredit bermasalah atau nonperforming loan di perbankan itu dapat disebabkan oleh berbagai faktor, misalnya ada kesengajaan dari pihak-pihak yang terlibat dalam proses kredit, kesalahan prosedur pemberian kredit, atau disebabkan oleh faktor lain seperti faktor makroekonomi. ${ }^{6}$ Dalam praktik, penyebab kredit bermasalah ini adalah ketika tidak ada kecukupan dana untuk membayar angsuran. Kondisi ini dilatarbelakangi oleh penurunan kemampuan bayar debitur, penyampaian informasi keuangan yang kurang detail pada

Iswi Hariyani, 2010, Restrukturisasi dan Penghapusan Kredit Macet; Kenapa Perbankan Memanjakan Debitur Besar sedangkan Usahal Debitur Kecil Dipaksa, Gramedia, Jakarta, hlm.39.

6 Hermansyah, 2011, Hukum Perbankan Nasional Indonesia, Kencana Prenada Media, Jakarta, hlm.75. 
saat pengajuan kredit sehingga menambah beban angsuran yang tidak bisa diantisipasi oleh debitur dan masalah di keluarga seperti cekcok rumah tangga, anggota keluarga sakit dan lain-lain. ${ }^{7}$ Budi Untung berpendapat, meskipun perbankan merupakan sektor yang strictly well regulated, tetapi kredit macet masih dapat terjadi. ${ }^{8}$

Kredit bermasalah dalam jumlah besar dapat mendatangkan dampak yang tidak menguntungkan bagi bank pemberi kredit, dunia perbankan pada umumnya, dan juga terhadap kehidupan ekonomi dan moneter suatu negara. ${ }^{9}$ Kredit bermasalah berawal dari wanprestasi debitur. Pada umumnya jenis-jenis wanprestasi dapat berupa tidak memenuhi prestasi, terlambat melakukan prestasi atau melakukan namun tidak sebagaimana mestinya. Adanya wanprestasi menjadi indikator dari adanya kredit bermasalah. Suatu kredit dikatakan bermasalah apabila ada keterlambatan pembayaran dari jadwal angsuran yang telah disepakati, atau kurangnya dana untuk melakukan pembayaran (terutama bila pembayaran dilakukan dengan sistem autodebet) dan tidak membayar sama sekali.

Untuk mencegah dampak yang lebih besar dari adanya kredit bermasalah terutama yang sudah dalam kategorikreditmacet, maka

Wawancara dengan Indah Trihana, Credit Admin Bank Tabungan Pensiunan Negara (BTPN), wawancara dilakukan pada 22 Desember 2014 dan dawancara dengan Ketut Gede Mardawa, Komisaris Utama BPR Aruna Nirmaladuta, wawancara dilakukan pada 24 Desember 2014.

8 H. Budi Untung, 2000, Kredit Perbankan di Indonesia, Andi Offset, Yogyakarta, hlm.121

9 Siswanto Sutojo, 2008, Menangani Kredit Bermasalah, Damar Mulia Pustaka, Jakarta, hlm.25.
Bank Indonesia mengeluarkan kebijakan mengenai penyelamatan dan penyelesaian kredit bermasalah, salah satunya adalah dengan restrukturisasi kredit.

Ketentuan restrukturisasi kredit mengacu pada ketentuan antara lain Undangundang di bidang perbankan, Peraturan Bank Indonesia dan Ketentuan internal masing-masing bank. Dalam Pasal 55 ayat (1) Peraturan Bank Indonesia Nomor 14/ 15 /PBI/2012 ditentukan bahwa bank wajib memiliki kebijakan dan prosedur tertulis mengenai restrukturisasi kredit. Sesuai dengan amanat Pasal 55 ayat (1) tersebut maka pihak bank wajib memiliki pedoman dalam melaksanakan restrukturisasi. Dalam praktik, belum semua bank memiliki pedoman atau ketentuan internal mengenai restrukturisasi kredit secara tertulis. Kebijakan restrukturisasi hanya didasarkan pada analisis kredit bermasalah dan kebijakan dari masing-masing bank bersangkutan.

Untuk menjaga obyektivitas, Restrukturisasi Kredit wajib dilakukan oleh pejabatatau pegawai yang tidak terlibat dalam pemberian kredit yang direstrukturisasi, namun dalam praktik, pengajuan kredit dan keputusan restrukturisasi dilakukan oleh bidang yang sama komite kredit yang terdiri dari kepala bagian kredit dan direksi. Restrukturisasi diajukan oleh marketing officer dan credit review disetujui oleh komite kredit. Kebijakan dalam memutuskan restrukturisasi kredit disesuaikan dengan kebijakan internal masing-masing bank. Adapula bank yang menunjuk petugas khusus yang memiliki batas wewenang memutus kredit sesuai dengan ketentuan bank. 
Restrukturisasi dilakukan sepanjang masih ada kemampuan membayar dan itikad yang baik dari debitur restrukturisasi kredit dapat dilakukan. Sebagaimana halnya pengajuan kredit maka pengajuan restrukturisasi harus atas inisiatif dari debitur. Analisis untuk memutuskan persetujuan terhadap restrukturisasi ini perlu dilakukan. Team leader kredit dan Marketing officer melakukan negosiasi untuk mencari solusi yang memungkinkan untuk dilakukan restrukturisasi kredit. Selanjutnya debitur membuat surat permohonan ke manajemen agar dapat dilakukan restruktur kredit. Analisis terhadap proses restrukturisasi ini dilakukan lebih detail untuk menyelamatkan kredit bermasalah.

Secara normatif sebagaimana yang telah dijelaskan sebelumnya cara yang dapat digunakan dalam restrukturasi dapat berupa penurunan suku bunga kredit, perpanjangan jangka waktu kredit, pengurangan tunggakan bunga kredit, pengurangan tunggakan pokok kredit, penambahan fasilitas kredit dan konversi kredit menjadi penyertaan modal sementara, namun dalam praktik yang paling sering digunakan hanyalah perpanjangan jangka waktu kredit. Hal ini disebabkan karena cara tersebut merupakan cara yang paling praktik dan tidak berisiko bagi bank sedangkan cara lain dipandang lebih sulit, misalnya pengurangan tunggakan bunga kredit tidak pernah dilakukan karena perhitungan bunga telah ditentukan melalui sistem.

Penyelamatan kredit bermasalah sedianya diberikan kepada semua debitur sepanjang masing memiliki kesanggupan membayar dan dapat membuktikan memang ada penurunan pemasukan. Dalam kenyataannya, bank cenderung memberikan kebijakan diskriminatif dimana kebijakan restrukturisasi hanya diberikan kepada debibur besar. Bank cenderung enggan untuk memberikan fasilitas restrukturisasi terhadap portofolio kredit macet milik debitur UMKM, khususnya debitur mikro dan debitur kecil. ${ }^{10}$

\section{Hambatan Dalam Restrukturisasi Kredit}

Kegiatan perbankan dilaksanakan berdasarkan prudential banking principles. Berdasarkan hal tersebut maka faktor finansial saja belum cukup untuk memberikan keyakinan bahwa fasilitas kredit tersebut akan kembali dengan aman dan menguntungkan. ${ }^{11}$ Dalam dunia perbankan penyelesaian kredit bermasalah dalam lingkungan administrasi perkreditan dilakukan sebagai salah satu upaya untuk menjaga kualitas kredit. ${ }^{12}$ Restrukturisasi kredit dalam penyelamatan kredit bermasalah merupakan suatu upaya yang ditawarkan dan menguntungkan baik dari pihak kreditur maupun dari pihak debitur. Menurut Badriyah Harun ada hal-hal yang perlu diperhatikan dalam penanganan kredit bermasalah yakni: ${ }^{13}$

\footnotetext{
Iswi Hariyani, op.cit., hlm.138.

Try Widiyono, 2009, Agunan Kredit Dalam Financial Engineering, Ghalia Indonesia, Bogor, hlm.2.

12 Muhamad Djumbana, 2006, Hukum Perbankan di Indonesia, Citra Aditya Bakti, Bandung, hlm.560.

13 Badriyah Harun, 2010, Penyelesaian Sengketa Kredit Bermasalah Solusi Hukum (Legal Action) dan Alternatif Penyelesaian Segala Jenis Kredit Bermasalah, Pustaka Yustisia, Yogyakarta, hlm.117.
} 
a. Keinginandebituruntukmenyelesaikan kewajiban.

b. Tingkat kerjasama dan keterbukaan debitur.

c. Kemampuan finansial debitur.

d. Sumber pengembalian pinjaman.

e. Prospek usaha debitur.

f. Mudah tidaknya menjual jaminan.

g. Kelengkapan dokumentasi jaminan.

h. Ada tidaknya tambahan jaminan baru.

i. Sengketa tidaknya jaminan.

j. Ada tidaknya sumber pembayaran dari usaha lain.

Dari faktor hukum, kebijakan restrukturisasi tertuang dalam aturan yang tersebar. Sampai saat ini belum ada ketentuan khusus yang mengatur mengenai restrukturisasi kredit. Peraturan kebijakan mengenai restrukturisasi kredit juga sering berubah-ubah. Faktor penegak hukum serta sarana dan fasilitas dalam penegakan hukum juga mejadi faktor penghambat dalam pelaksanaan restrukturisasi kredit manakala terjadi keterbatasan baik finansial maupun tenaga staf yang ahli di bidang restrukturisasi serta koordinasi antar lembaga. Pemahaman mengenai peraturan tentang restruktukrisasi perlu dilakukan. Penentuan kebijakan mengenai restrukturisasi dalam praktik dilakukan oleh bidang yang sama dengan yang menentukan pemberian kredit. Hal ini dapat menimbulkan subjektivitas dalam memberikan persetujuan restrukturisasi.

Oknum pihak bank melaksanakan restrukturisasi kredit hanya untuk kepentingan formalitas saja, debitur juga kurang mendapatkan informasi mengenai restrukturisasi ini. Dalam Peraturan Bank
Indonesia sebagaimana telah diuraikan sebelumnya ditentukan bahwa kredit kepada Pihak Terkait yang akan direstrukturisasi wajib dianalisis oleh konsultan keuangan independen yang memiliki izin usaha dan reputasi yang baik. Keterlibatan konsultan keuangan independen seringkali diabaikan karena melibatkan konsultan keuangan independen berarti menambah biaya yang dikeluarkan untuk mengatasi kredit bermasalah. Biaya ini akan memberatkan pihak debitur yang dalam kondisi tersebut memang memilikikesulitan untukmembayar, dan jika dibebankan kepada kreditur, kreditur pun akan dirugikan lebih banyak lagi.

Restrukturisasi kredit sangat mudah dilakukan sepanjang ada itikad baik dari nasabah selaku debitur. Hambatan yang selama ini sering terjadi pelaksanaan restrukturisasi kredit adalah nasabah yang tidak kooperatif. Pelaksanaan restrukturisasi kredit dalam penyelamatan kredit bermasalah merupakan pelaksanaan dari aturan yang mengatur tentang restrukturisasi. Menurut Munir Fuady, salah satu cara untuk memberikan perlindungan kepada nasabah adalah dengan melaksanakan peraturan yang ada di bidang perbankan secara lebih ketat oleh pihak otoritas moneter. ${ }^{14}$ Dengan demikian, pelaksanan ketentuan restrukturisasi merupakan upaya dalam melindungi nasabah.

14 Munir Fuady, 2003, Hukum Perbankan Modern, Citra Aditya Bakti, Bandung, hlm.104. 


\section{PENUTUP}

\section{Simpulan}

Berdasarkan pembahasan yang telah diuraikan sebelumnya maka dapat disimpulkan sebagai berikut:

1) Implementasi ketentuan restrukturisasi kredit dalam penyelamatan dan penyelesaian kredit bermasalah pada kredit perbankan belum optimal diterapkan terhadap semua debitur yang mengalami kesulitan membayar meskipun masih memiliki peluang untuk melaksanakan pembayaran. Restrukturisasi kredit biasanya hanya dilakukan dengan perpanjangan jangka waktu kredit saja karena cara-cara yang lain penurunan suku bunga kredit, pengurangan tunggakan bunga kredit, pengurangan tunggakan pokok kredit, penambahan fasilitas kredit, dan/atau konversi kredit menjadi penyertaan sementara dianggap lebih sulit dan berisiko menimbulkan kerugian yang lebih besar bagi kreditur. Kebijakan internal melalui prosedur dan kebijakan tertulis mengenai restrukturisasi belum dimiliki oleh semua bank.

2) Hambatan yang dihadapi dalam implementasi ketentuan restrukturisasi kredit dalam penyelamatan dan penyelesaian kredit bermasalah pada kredit perbankan adalah dari faktor hukum yakni peraturan mengenai restrukturisasi kredit yang tersebar dalam berbagai peraturan kebijakan, seringnya peraturan berganti dengan jumlah peraturan yang relatif banyak, dari segi faktor penegak hukum dan sarana penegakan hukum yang dalam hal ini adalah bank dan sarananya terdapatbelumadanyapemahamanyang komprehensif mengenai kebijakan ini. Bidang yang memberikan persetujuan restrukturisasi sama dengan bidang yang memberikan persetujuan kredit. Konsultan keuangan independen seringkali diabaikan keterlibatannya dalam restrukturisasi kredit. Faktor masyarakat dan budaya yang menghambat restrukturisasi kredit adalah itikad yang tidak baik untuk melaksanakan kesepakatan, kurangnya informasi dan inisiatif debitur dalam mengajukan restrukturisasi kredit, nasabah yang tidak koorperatif dan pemberian data yang tidak benar mengenai sumber penghasilan.

\section{Saran}

Rekomendasi yang dapat disampaikan mengenai implementasi ketentuan restrukturisasi kredit bermasalah pada kredit perbankan adalah:

1) Bank Indonesia hendaknya tidak terlalu sering mengganti kebijakan mengenai restrukturisasi kredit dalam penyelamatan kredit bermasalah. Masing-masing bank hendaknya memiliki kebijakan dan prosedur tertulis mengenai restrukturisasi kredit, memiliki divisi khusus yang menentukan restrukturisasi dan membedakannya dengan divisi pengajuan kredit. Bank hendaknya memberikan pelatihan bagipegawainya dalam meningkatkan pengetahuan 
mengenai kebijakan restrukturisasi dan prediksi dalam mengukur kesanggupan dan kemampuan membayar melalui prospek usaha debitur yang menjadi sumber pendapatan untuk melaksanakan pembayaran.

2) Debitur yang dalam hal ini adalah nasabah bank hendaknya memiliki itikad baik untuk melaksanakan prestasi, mau kooperatif dalam setiap tahapan pengajuan restrukturisasi, memberikan informasi dan data yang benar guna mencapai kesepakatan dalam restrukturisasi. Jika debitur telah kooperatifdalam hal ketidaksanggupan membayar, maka pihak bank hendaknya memberikan kesempatan dalam memberikan kesempatan restrukturisasi kredit kepada nasabah sebelum mengambil keputusan untuk menjual agunan guna menutupi pembayaran kredit.

\section{DAFTAR PUSTAKA}

Badriyah Harun, 2010, Penyelesaian Sengketa Kredit Bermasalah Solusi Hukum (Legal Action) dan Alternatif Penyelesaian Segala Jenis Kredit Bermasalah, Pustaka Yustisia, Yogyakarta.

Bambang Sunggono, 2010, Metode Penelitian Hukum, Rajawali Pers PT. Raja Grafindo Persada, Jakarta.

Budi Untung, H., 2000, Kredit Perbankan di Indonesia, Andi Offset, Yogyakarta.

Djumbana, Muhamad, 2006, Hukum Perbankan di Indonesia, Citra Aditya Bakti, Bandung.
Hermansyah, 2011, Hukum Perbankan Nasional Indonesia, Kencana Prenada Media, Jakarta.

Iswi Hariyani, 2010, Restrukturisasi dan Penghapusan Kredit Macet; Kenapa Perbankan Memanjakan Debitur Besar sedangkan Usaha/Debitur Kecil Dipaksa, Gramedia, Jakarta.

Munir Fuady, 2003, Hukum Perbankan Modern, Citra Aditya Bakti, Bandung. Sigit Traindaru dan Totok Budisantoso, 2007, Bank dan Lembaga Keuangan Lain, Salemba Empat, Jakarta.

Siswanto Sutojo, 2008, Menangani Kredit Bermasalah, Damar Mulia Pustaka, Jakarta.

Soerjono Soekanto, 2007, Pengantar Penelitian Hukum, PenerbitUniversitas Indonesia (UI-Press), Jakarta.

Try Widiyono, 2009, Agunan Kredit Dalam Financial Engineering, Ghalia Indonesia, Bogor.

\section{Kitab Undang-Undang Hukum Perdata (KUHPerdata)}

Undang-Undang Nomor 7 tahun 1992 tentang Perbankan sebagaimana diubah menjadi Undang-Undang Nomor 10 tahun 1998 tentang Perbankan.

Undang-Undang Nomor 23 tahun 1999 tentang Bank Indonesia.

Peraturan Bank Indonesia Nomor: 13/9/ PBI/2011 Tentang Perubahan Atas Peraturan Bank Indonesia Nomor 10/18/PBI/2008tentangRestrukturisasi Pembiayaan Bagi Bank Syariah dan 
Unit Usaha Syariah.Peraturan Bank Indonesia Nomor 14/ 15 /PBI/2012 Tentang Penilaian Kualitas Aset Bank Umum.

Peraturan Bank Indonesia Nomor 15/2/ PBI/2013 tentang Penetapan Status dan Tindak Lanjut Pengawasan Bank Umum Konvensional.Surat Edaran No. 15/28/DPNP kepada Semua Bank Umum yang Melaksanakan Kegiatan Usaha Secara Konvensional di Indonesia. 